\title{
Kingdom of God or justification of the sinner? Paul between Jesus and Luther
}

\author{
J. van Bruggen \\ Theologische Universiteit Kampen \\ KAMPEN \\ Nederland \\ E-pos: JakobVanBruggen@wxs.nl
}

\begin{abstract}
Kingdom of God or justification of the sinner? Paul between Jesus and Luther

This article discusses the much-debated tension between Jesus' message and Paul's message. The new Paul-paradigm changed the debate. Especially the work of J.D.G. Dunn raises the question as to whether the process of de-Lutherising Paul of necessity leads to the re-Judaising of Paul? The article concludes that there is not really a tension between the message of the kingdom of God and the gospel of the justification of the sinner.
\end{abstract}

\section{Introduction}

The message of both John the Baptist and Jesus was about the kingdom of God. Not only did they frequently use the terminology of the kingdom from the very beginning, but others also use this same terminology to characterise and summarise the preaching of the Lord and his forerunner.

Paul seems to be an exception. Is he not the apostle of the justification of sinners, first the Jew and also the Greek? What clearly forms the centre in the Gospels seems to be marginalised in Paul's Epistles.

So it is natural and not surprising that Luther found his personal way to paradise especially through Paul. There is a direct connection between the apostle of the nations - the preacher of justification - and the German Reformer of justification by faith alone. 
But what about the apparent discontinuity between Paul and Jesus? Is there a contrast between the message of the kingdom for this world and the preaching of the justification for sinners? Or do we read Paul through the eyes of Luther instead of through the gospel of Jesus, and are we thereby creating a discontinuity that in reality did not exist? Is the discontinuity not between Paul and Jesus but rather between Luther and Paul?

\section{Recent moves}

\subsection{Discontinuity between Luther and Paul - or between Paul and Jesus?}

The latter possibility has been defended by different admirers of the socalled new Paul-paradigm. They claim that we have misunderstood Paul for more than four centuries and that we have to de-Lutherise St. Paul and to view him again within the structure of Judaism in order to also reunite him with Jesus, teacher in Israel.

The more we disconnect Luther and Paul, the more we seem to get opportunity to bridge the gap between Paul and Jesus that was discussed for more than two centuries in the old Paul-paradigm. Many theologians in the 19th and 20th century have drawn the picture of a Jewish Jesus and a Hellenised Paul: in fact, they claim that Paul should be considered the real betrayer of the original gospel, who built a nonJewish Christology out of the simple, Jewish message of the kingdom of God, the kingdom of love, as we find it in the preaching and life of Jesus.

\subsection{Back to Jesus to find the kingdom?}

In the 20th century this view on Paul and Jesus had to retreat for a certain period under the influence of the anti-liberal theology of Kart Barth. But at the end of the 20th century this view on Jesus as a simple and original teacher has regained its old influence. Many theologians returned to the denial of the atoning power of Jesus' death and to the reduction of Jesus to a Jewish prophet. As a result the kernel of the Gospel is at the same time no longer atonement but the kingdom of God1.

1 The old battle started again in Holland with the book of Den Heyer, Verzoening: bijbelse notities bij een omstreden thema (1997). The doctrine of atonement was defended in publications like Verzoening, daar draait het om (Hoek, 1998); Het evangelie van de verzoening (Baarlink, 1998); Om het hart van het evangelie. Een boek voor de gemeente over de verzoening (Elsinga, 1998). Regarding this issue, also see God en mens verzoend: incarnatie, verzoening, koninkrijk van God (Wentsel, 1991). 
The renewal of an old dilemma (kingdom or atonement) became very visible in a couple of Dutch lectures published in the series "Leidse lezingen". The translated title is Atonement or Kingdom: about the priority in preaching the gospel (Van den Brom a.o.,1998). In this publication we find an article entitled "Eerherstel voor het koninkrijk" (Rehabilitation of the kingdom), in which De Jonge defends the priority in preaching of what Jesus taught about the kingdom of God. ${ }^{2}$ The person of the Christ disappears as belonging to later dogmatics behind the doctrine of the human Jesus about the heavenly kingdom. This theme should be far more important than the theme of atonement that has been popular since the Reformation.

Als het hoofdthema in de prediking en daarmee in de theologie moet zijn: Gods aanbrekend koningschap en de van mensen geëiste gehoorzaamheid, dan zal het gevolg zijn dat andere thema's hun centrale plaats moeten afstaan. Dat geldt speciaal voor het thema van de verzoening door Jezus' dood. Niet dat dat onderwerp uitgebannen moet worden. Maar het moet een minder belangrijke plaats krijgen (De Jonge, 1998a:15).

(Summarised: If the message of God's coming kingdom is the central point of preaching and theology, other themes have to give up their central place and become less important.)

See also De Jonge, 1998b:82:

Een christelijke soteriologie zonder verzoening door de dood van Jezus kan, in het licht van de geschiedenis, aanspraak maken op legitimiteit. Ze gaat terug op Jezus zelf.

(Summarised: In the light of the historical development a soteriology without atonement through the death of Jesus, has a legitimate place!)

\subsection{The new paradigm in Pauline studies (Dunn)}

Whenever there is a shift in opinion about the centre of Jesus' message, Paul becomes involved. The move is made from atonement to kingdom, and at that moment Paul becomes a solitary pawn in the centre of the

2 A decisive place has the idea of De Jonge that the resurrection of Jesus originally was meant not as a corporal resurrection on earth but as a spiritual resurrection or rehabilitation in heaven. This concept of heavenly rehabilitation originated in the theology of the martyrs: dying on earth and being "resurrected" in heaven. So in fact the original kerugma of the resurrection was not about Jesus himself, but about the vindication of his message of the kingdom by God. See for a broader discussion of this idea of De Jonge Jesus the Son of God: The Gospel Narratives as Message (Van Bruggen, 1999:193-194) 
chessboard. The next moves are made with this advance pawn, not only in the old Paul-paradigm, where he is taken from the board, but also in the new Paul-paradigm, where he is moved away from Luther and pushed in the direction of the Jewish Jesus, the prophet of the kingdom.

The issue at stake is whether there is a discontinuity between the gospel of the universal kingdom and the message of the individual justification of the sinner. In other words: did the original message of a new world disappear behind the later Christology and soteriology aimed at individuals? Is a return to the message of the kingdom in fact the same as the archaeology of the original message of God, which through the centuries has gradually been buried under the dust of personal theology?

I take my starting-point in the publications of James D.G. Dunn, because he is the best-known spokesman of the new paradigm among theologians and preachers. Mostly Dunn speaks about the interpretation of the Law as the point of misunderstanding between Luther and Paul. This point, however, is connected with our issue of the kingdom. This becomes apparent in a relatively small publication entitled The Justice of God: A Fresh Look at the Old Doctrine of Justification by Faith (Dunn \& Suggate, 1993). In this publication, written in cooperation with Alan M. Suggate, Dunn stresses the point that Luther has individualised the Hebrew, social concept of righteousness. As soon as we see the concept of righteousness not as individual but as social, ethnic, universal, it comes very close to the concept of the kingdom of God. The "justice of the kingdom" is the non-individual justice of God in society. The second part of the book contains case-studies about this justice of the kingdom by Suggate. The discussion involves secular issues: Germany (the doctrine of the two reigns), Japan (the mission of the emperor), and England (free market and faith).

The more the justice of the kingdom is painted in the colours of society, the more the personal justification of the sinner through the sacrifice of Christ is marginalised. Dunn acknowledges the existence of this margin, but at the same time he accepts that it is not so clear exactly where the margin lies: it is a matter of dispute. In his opinion this is not a great problem because it does not belong to the central issues of Paul's theology (Dunn \& Suggate, 1993:9):

[I]n Christian thinking 'justification by faith' is closely tied-in to belief about Jesus' death on the cross. The teaching of Paul is that Jesus' death somehow makes satisfaction before God for the sin of others. [...] But how this comes about has been a matter of dispute between Christians. Was Jesus' death a sacrifice? [...] But how did that make the difference for God? Did Jesus somehow become a substitute for others in his death? 
Dunn questions whether this does not apply the law-court metaphor too rigidly and how this sacrifice is repeated in the eucharist? And do we have to speak about gratia infusa or gratia imputata - grace infused or grace imputed?

In reaction to all those questions Dunn \& Suggate (1993:10) says:

Fortunately such disputes have been largely overcome, with each side recognising the importance of the emphasis made by the other. Important as they are, we need not go into them further here. If readers so desire they can pursue them further in the reading suggested at the end.

Thus Dunn in fact minimalises the importance of the atonementlanguage because of too many uncertainties.

With Dunn as representative for the new Paul-paradigm Paul not only becomes de-Lutherised, but also the whole Gospel becomes deChristologised on behalf of the supremacy of the Spirit of the Almighty. In fact, the justice of the kingdom is the spirit of the kingdom (see Dunn, 1998:190-191).

\section{Discussion}

\subsection{Jesus and the Kingdom}

\section{The pattern of Jesus' life}

In the Gospels we experience a remarkable development. Jesus starts with the preaching of the kingdom, broad and world-wide in scope. The unlimited importance of this theme is demonstrated by many, many healings and by the expulsion of the demons from the human world. Really signs of a divine kingdom! (see Van Bruggen, 1999: chapter 3).

But reading further in the Gospels the miracles seem to become less important. More and more we hear about suffering. Many distance themselves from Jesus. And finally his life ends in loneliness, prison, and death. Is this the tragic of a world-reformer? No, because Jesus himself frequently makes clear that He has chosen this way. The preacher of the kingdom prefers the road to the hill of the cross in the desert. That is his incomprehensible strategy!

Frequently Jesus speaks about "my hour": the hour of his suffering, death, resurrection, and glorification. That hour has the splendour of the kingdom of glory, but it points to Getsemane. 
Just in the last minutes before that hour, Jesus has broken the bread: "This is my body for you: remember Me!" Even the diehards among critics have to acknowledge that Jesus instituted something like the Lord's Supper, because we cannot find any explanation for this ceremony outside of the historical Jesus.

However, when Jesus' life on earth shows a direct connection between the conqueror of the demons and the dying prophet, it becomes very difficult to separate the message of the kingdom from the day of universal atonement.

\section{The sequel after Easter}

Such a separation is all the more impossible because the perspective of the kingdom is still fully present after Jesus' death. His death is followed by his glorious resurrection: the conqueror of the demons is also the conqueror of death! And his ascension makes it clear that He is no longer bound by the gravity of the earth that separates mankind from the angels. The ascension is accompanied by the promise of the restoration of all things! And in the book of Acts we hear again about healings and exorcisms. All this shows that we did not lose track of the kingdom on the way of the cross: on the contrary!

The atonement through sacrifice is the last remedy in this world of sinners and death to restore the lost kingdom of heaven. There is no discrepancy between kingdom and justification in Jesus' life. His remarkable way of living and dying can be understood as soon as we acknowledge that the kingdom of God has to return in a world that has closed its doors to God in enmity against God Himself.

\section{Fragmenting the Gospels}

The separation between atonement and kingdom, so commonly held today, is only possible at a great price. This price is that we have to deny the gospel as history and as message presented through facts. If we reduce the gospels of the apostles and eyewitnesses to a loose collection of separate words by Jesus, connected by a fictional framework of stories, we create an unbridgeable abyss between the prophet and the king, between the teacher and the leader. This is the regrettable sickness of modern biblical scholarship in the Western world. History is exchanged for stories, facts disappear behind legends of the ancient church-community. You can focus on the potsherds while missing the beauty and design of the original, undamaged pottery!

In summary, Jesus' preaching about the kingdom of heaven, in combination with his life on earth, makes it impossible to view such topics as his life, his person, and his task as belonging to a secondary Christology, 
added later by the Christian community to the original, simple teaching of Jesus about the kingdom of God. The way in which he speaks about this kingdom - against the background of John's preaching and with the authority of a judge - places his own person and his work at the very centre of attention.

\subsection{Paul and the kingdom of God}

To determine the central message of Paul, we must look at his sermons in Acts and the broader background of his Epistles, since on the surface his Epistles are far too limited to special situations and specific problems to extrapolate from them the fundamentals of his preaching.

When we analyse his sermons and the supposed background and foundation of his letters, we find also in Paul (as in the other apostles) the close connection between the expectation of the kingdom of God and the person of Jesus Christ.

\section{Preaching in the Diaspora}

In Acts, "preaching the kingdom" is a way of characterising apostolic preaching in general (Acts 8:12; 14:22; 19:8; 20:25; 28:23). Although in the Epistles we regularly find allusions to the preaching of the kingdom (1 Thess. 2:12; 1 Cor. 4:20; Gal. 5:21; 2 Pet. 1:11; James 2:5, etc.), the frequency with which the kingdom is mentioned drops sharply. In its place the expression preaching Christ or preaching the gospel gains prominence. This would seem to be a shift in emphasis - from an expected reality to a revered person. But this apparent shift becomes more understandable in light of the way in which Jesus taught the secrets of the kingdom of heaven (see Feine, 1919). The formulation of his message was aimed at his immediate context: Jews under the spell of the Baptist. What he taught about himself is therefore also often expressed in the terminology of the coming kingdom.

But in the Diaspora this specific context (Jews under the spell of the Baptist) did not exist. For this reason the horizon, the expected kingdom of heaven, is still present in Acts and the Epistles, but the path to the kingdom (Christ) is preached more directly and now receives all attention as the trajectory of faith immediately before us.

\section{Kingdom and King}

Paul and Peter view the kingdom of God as the new order that will become a reality on earth when Christ appears. The nearness of this kingdom thus becomes the nearness of the Lord (Phil. 4:5; Rev. 22:12). Faith in Christ, and justification with sanctification as the way to enter the kingdom, now become the framework within which the dynamic 
equivalence of what Jesus taught about the smallness of the kingdom, its simplicity, and so forth, is presented. And the reality of the connection between faith and the coming kingdom now becomes apparent in the first gift, the Holy Spirit. When Paul says that God has "brought us into the Kingdom of the Son he loves" (Col. 1:13), he does not mean that this kingdom is the Christian community. Rather, he is speaking about the indissoluble tie that already exists with the kingdom of heaven. Thus he also says with regard to people who are still living on earth: "God raised us up with Christ and seated us with him in the heavenly realms in Christ Jesus" (Eph. 2:6). At the same time, the certainty of the faith of the people who know that they are already citizens of that kingdom through the Spirit, and who, through this Spirit, already share in its first gifts, does not rule out the fact that entering into this kingdom is still future, so that Paul can write, "The Lord will rescue me from every evil attack and will bring me safely to his heavenly Kingdom" (2 Tim. 4:18).

The fact that the terminology of "the kingdom of God" is not central in the later development of the teaching of the church is thus consistent with the flow of history. The early church and the Reformation church clearly understood the striking way in which Jesus dealt with the concept of the kingdom of God when they placed the satisfaction by means of Jesus' atoning death and the salvation through God's only Son at the centre. Today the gospel of the kingdom of God consists in bestowing the power of faith in Christ. This faith preserves us and lets us inherit the future. The Spirit of God, who already lives in all believers, is the pledge of the promised inheritance, for which we now pray with confidence: "Thy kingdom come."

\subsection{Luther, Dunn, and Paul}

Did Luther misunderstand Paul and have the churches of the Reformation under his influence lost the social concept of the kingdom and only preserved the individual and soteriological concept of justification? This is a current accusation, also heard in the books of Dunn.

At this point we have to face three questions: 1 . Who is the real Luther? 2. Who is the real Dunn? 3 . Who is the real Paul?

\subsection{Who is the real Luther?}

Luther is charged with changing the focus from objective righteousness to individual, subjective righteousness, with the effect that the salvation of the individual soul suppressed the justice of the kingdom of God. All this was the result of the Luther's wrong vision of the law, of the Jews, and therefore of Paul (see Dunn \& Suggate, 1993). 
Is this really Luther? In fact, Luther is not so one-sided. In the preface to the first volume of his collected Latin works he tells us how he gradually came to his specific conviction. He acknowledges that he was influenced by the writing and teaching of Augustine (Weimarer Ausgabe 54,186,2529). The word of Romans 1,17 became decisive to him in this process. He stumbled over the word "God's righteousness" because he interpreted it as God's righteousness in punishing (iustitia formalis seu activa) (Weimarer Ausgabe 54,185,17-20). Gradually, however, God showed him the connection of Romans 1,17a with 1,17b ("the righteous shall live through faith"). So Luther concluded that Paul was writing about God's righteousness by which we are justified (iustitia Dei passiva). Luther felt himself reborn (renatus) and walked through an open door into paradise (Weimarer Ausgabe 54,186,3-9). From this perspective he started to read the Psalms and the whole Bible. And to his relief he found Augustine on his side.

What happened with Luther was not primarily an exegetical discovery, since through the centuries there have always been two options for understanding God's righteousness in Romans (see Schelkle, 1956). The history of interpretation makes it clear that you can defend either the active or passive interpretation of dikaiosunè and at the same time make no connection at all with the punishment of an angry God. 3 What happened to Luther was very personal. As a person Luther had to become free from a distorted image of God, a distortion that for him had become integrated with the active interpretation of the word dikaiosunè. When Romans 1,17 became the door of paradise for Luther (porta paradisi), we see above that door the word "private": the connection between Romans 1:17 a and 17b was very personal indeed.

Luther's change was at the level of the retributive justice of God and not at the level of the restoring justice of God. He did not deny that restoring justice, but he focused on the retributive justice because he had had a personal problem at that point. As a result Luther distorted some words of Paul a little, but we cannot say that Luther as a Christian and as a preacher limited the justice of God in an unsocial way to individual salvation.

3 In the ancient church the active interpretation does not function as negative and retributive. Also after Luther the choice of interpretation is changing between active (Käsemann) or passive (Cranfield) without any connection at all with the punishment-idea. Reformed interpreters like Greijdanus, Jager, Schlatter and Sanday-Headlam prefer the active interpretation sharing the conviction of Luther about justification. At the other side Ridderbos prefers, as Luther, the passive interpretation and at the same time shows a remarkable deviation from Luther by making the justification completely forensic. 
Luther was fully aware of the social justice of God, as is made clear by his reinterpretation of the fourth petition in the Lord's prayer after the Peasant's War. In his shorter Catechism he changed the interpretation into a very worldly one about government, neighbours, bread, and society. 4

Protestant Christianity in later times sometimes became limited to the individualism of pietism, while interest in this world, politics, and environment diminished. For that development Luther cannot be blamed, however. For him the doctrine of the kingdom fits with the doctrine of justification, just as access to the palace is available only by means of the proper key.

\subsection{Who is the real Dunn?}

Luther was struggling with the justification of the sinner, but Dunn and others today are wrestling with the justification of the Jews. In fact, this is a cross-over. Dunn and others follow the work of Moore and accept that Judaism was not as legalistic and casuistic and as nationalistic as the Reformers thought. And indeed, we have to acknowledge that Luther, Calvin, and others have painted the Jews with the colours of RomanCatholicism: the Sanhedrin became the counterpart of the pope and his cardinals, and the Roman doctrine of earning merits by good works became the starting point for interpreting what Paul wrote about works of the law. In the 19th century, the religion of the Jews was seen as a distortion of the original Israelite prophetic religion. So Jesus and Paul became in fact non-Jews in order to go back to the original religion of Abraham. There is more than once an anti-Semitic flavour in these theories: the Christians are the true successors of Israel, while the Jews are traitors to their religion! It is a good thing that we are becoming liberated from those distorted views of Judaism. More and more we see how multifaceted Judaism was in the first century. Jesus did not come to destroy Judaism (whatever it may have been), but to destroy the works of Satan in the Jewish world.

Repainting the colours of Luther's interpretation of Paul does not, however, mean that we have to abandon his painting of God's justification through faith in the atonement by Jesus Christ. Yet this is precisely what happens with Dunn and most of the defenders of the new Paul-paradigm. Christ as

4 In 1519 Luther gave an explanation of the fourth petition that is completely devoted to spitiual issues, such as grace, preaching, eucharist, government, mission, comfort ("Eine kurze Form, dass Vaterunser zu verstehen und zu beten"). In 1529 ("The shorter catechism") his explanation has turned to worldly issues such as: body, clothing, neighbours, shoes, house, cattle, money, weather, peace, friends a.s.o. 
the Son of God disappears and becomes a true son of the repainted Israel. The atonement disappears behind a religious social prophet. This would seem to be the unavoidable consequence of the new paradigm of Judaism. In fact, however, it is the result of a quite different movement made at the same time, but unconnected with the repainting of Judaism.

When Dunn no longer maintains the central importance of the atonement in Paul, it is not due to the detachment of Paul from Luther at the level of our understanding of the nature of Judaism. The centre of Luther's conviction is not built on his ideas about Jews but on his reading the Gospels. In the same way the detachment of Jesus and Paul from the doctrine of the atonement by Dunn is not really connected with his understanding of the nature of Judaism. The centre of Dunn's conviction is built upon his destruction of the Gospels and his changing them into patches of original words of Jesus in a largely fictional setting. So in fact the new Paul-paradigm is partly Gospel criticism in disguise!

This statement is supported by reading Dunn's works as a whole. His works show a critical consistency. Already a short sketch of his earlier publications can illustrate this. There is one consistent theological line: the centre is no longer Christ but the Spirit, and the fundamental thing is no longer history and revelation, but experience.

In 1970 Dunn wrote Baptism in the Holy Spirit. He summarises the results in four sentences that show how decisive the Spirit is for faith: Faith is shown to be genuine only by the gift of the Spirit.

Faith demands baptism as its expression; Baptism demands faith for its validity. The gift of the Spirit presupposes faith as its condition; Faith is shown to be genuine only by the gift of the Spirit (Dunn, 1970:228).

Dunn's next book is entitled Jesus and the Spirit. A Study of the Religious and Charismatic Experience of Jesus and the First Christians as Reflected in the New Testament (Dunn, 1975). Here he makes clear that the experience of the Spirit is not the same as accepting the revelation. Jesus himself was moved by the experiences of God the Spirit. Dunn (1975:361) writes:

Their theology was produced out of the living dialectic between the religious experience of the present and the definitive revelation of the past (the Christ event), with neither being permitted to dictate the other, and neither being allowed to escape from the searching questions posed by the other - an unceasing process of interpretation and reinterpretation. 
Inevitably his third book has to deal with the Christology: does Christ disappear behind the Spirit? The title is Christology in the Making (Dunn, 1980). To our surprise the orthodox doctrine of incarnation is exchanged for the modern, humanistic theology of Jesus as the centrepoint of humanity: God makes clear how human He really is!

In substance the trinitarian confession means that God in Jesus Christ has proved himself to be self-communicating love and that as such he is permanently among us in the Holy Spirit (Dunn, 1980: 268).

It is then no surprise that in his Theology of Paul (Dunn, 1998) Dunn reduces the language of Paul about the death, resurrection, and return of Jesus Christ to metaphorical language. Jesus' statements are not dogmatic or objective; rather, they form the working out of the Christian experience of the Spirit. It is mostly about real experience but not about facts. At the same time Dunn speaks more about the unity of God than about the divine nature of Christ or the Trinity.

The reality of Dunn is that he makes a separation between the King Jesus and the kingdom. For Dunn the kingdom of God is the kingdom of the Spirit, preached by Jesus and Paul. His de-Christologising of the Kingdom is destructive for the doctrine of the justification of the sinner. It is, however, also destructive for the doctrine of the kingdom of God. This new approach results in horizontal activism in the name of the kingdom of God but without a King of salvation.

\subsection{Who is the real Paul?}

Paul's doctrine about the justification of the sinner seems connected with his negative attitude toward "works", and this seems to have a negative effect upon the promotion of the justice of the kingdom.

In fact, Paul only speaks about this issue in two of his thirteen letters: Galatians and Romans. In both of them he is arguing with non-Jewish readers. He is warning them not to return to "works". But how could they return to works? They had never been Jews under the Law at all! It is a current idea that "works" is a specific concept of the Law and the Jews. This is not true, however. Josephus never discusses Judaism in terms of works. And the modern study of Judaism and Paul has made clear that Judaism was not nomistic or legalistic. In fact, the non-Jewish religions were! The Gentiles tried to deserve the grace of the Gods. Seen from the gentile point of view the Jews similarly perform good works for their god, and this is why some gentile Christians feel themselves invited to share the Jewish way of working for the god. At this point Paul enters the discussion. Using the gentile view of religion and their idea about the religion of the 
mosaic law, Paul makes it clear that they are mistaken. The religion of Abraham is a religion of faith and not of works and merits. The religion of the Lord of Abraham is quite different from the way they perceive it. Therefore, having returned to the obedience towards the Creator and having received faith in Jesus the Messiah, why return to something that seems similar to their original gentile way of serving the Gods - through works? (see Van Bruggen, 2001).

At the level of religion (the attitude towards the Creator) works are a gentile misunderstanding. A quite different thing is the human attitude and way of life in this created world. At that point Paul gives direction. The children of the heavenly kingdom have their responsibility on earth, because the earth is the Lord's!

\section{Conclusions}

\subsection{The Scriptures and history}

In order to avoid misinterpretations we must read the texts in the Bible in their historical context as the most natural frame of reference. The Bible is not a textbook about kingdom or justification, easy for quick and simplistic conclusions. The Bible contains documents that are embedded in a history. On the one hand this makes them more limited and specific as texts, on the other hand it gives them roots in the wider context of God's history with this world. Let me illustrate this with two remarks, one more hermeneutical, the other more theological.

- It is hermeneutically necessary to distinguish between the dominant ideas of the apostles (mostly in the background behind their Epistles) and their specific and limited advice in epistles to individual persons and churches.

- The theological dialectical scheme of the "already" and "not yet" of the kingdom needs revision: we have to speak about a partial "already" (in heaven and through the Gift of the Spirit) and a partial "not yet" (as far as the Devil and death have yet influence and power for a certain time). We are already justified through faith in the King, but we have not yet entered the kingdom itself, although we have received the "advance or first installment" of the Spirit.

\subsection{Faith and world}

To avoid the extremes of individualistic pietism and religious-social activism, it is necessary to carefully sketch the connection between and interrelation of God's kingdom and the justification of the sinner. They are 
related as key and palace. You cannot enter without the key and the key allows entry into the world of the King!

The Reformed churches have two connected tasks in their preaching: to preach the gospel of grace for the sinner, and to make clear how this grace opens the way to world-bound responsibility on a social, political, and environmental level.

It is important that the social, political, and environmental responsibility of the children of the kingdom remains connected with their faith in Jesus Christ in order to prevent humanistic idealism and lack of fervent hope and strong prayer. We should pray "Thy kingdom come!" and at the same we tremble and humbly ask: "Forgive us our trespasses!"

\section{Bibliography}

BAARLINK, H. 1998. Het evangelie van de verzoening. Kampen : Kok.

DE JONGE, H.J.J. 1998a. Eerherstel voor het koninkrijk. (In Van den Brom, L.J. e.a. Verzoening of Koninkrijk. Over de prioriteit in de verkondiging. Leidse lezingen. Nijkerk/Kampen : Callenbach. p. 9-20.)

DE JONGE, H.J.J. 1998b. De plaats van de verzoening in de vroegchristelijke theologie. (In Van den Brom, L.J. e.a. Verzoening of Koninkrijk. Over de prioriteit in de verkondiging. Leidse lezingen. Nijkerk/Kampen : Callenbach., p.63-90.)

DEN HEYER, C.J. 1997. Verzoening: bijbelse notities bij een omstreden thema. Kampen : Kok.

DUNN, James D.G. 1970. Baptism in the Holy Spirit. A Re-examination of the New Testament Teaching on the Gift of the Spirit in Relation to Pentecostalism. Studies in Biblical Theology 2,15. London : SCM Press.

DUNN, James D.G. 1975. Jesus and the Spirit. A Study of the Religious and Charismatic Experience of Jesus and the First Christians as Reflected in the New Testament. London : SCM Press.

DUNN, James D.G. 1980. Christology in the Making. An New Testament Inquiry into the Origins of the Doctrine of the Incarnation. London : SCM Press.

DUNN, James D.G. 1998. The Theology of Paul the Apostle. Edinburgh : Clark.

DUNN, James D.G. \& SUGGATE, Alan M. 1993. The Justice of God: A Fresh Look at the Old Doctrine of Justification by Faith. Carlisle : Paternoster.

ELSINGA, C.B., ed. 1998. Om het hart van het evangelie. Een boek voor de gemeente over de verzoening. s.l. : Uitgeverij CeGe boek.

FEINE, P. 1919. Theologie des Neuen Testaments. 3rd ed. Leipzig : Hinrichs.

HOEK, J. 1998. Verzoening, daar draait het om. Zoetermeer : Boekencentrum.

SCHELKLE, K.H. 1956. Paulus, Lehrer der Väter: die altkirchliche Auslegung von Römer 1-11. Düsseldorf : Patmos Verlag.

VAN BRUGGEN, Jakob. 1999. Jesus the Son of God: The Gospel Narratives as Message. Grand Rapids : Baker.

VAN BRUGGEN, Jakob. 2001. Paulus: pionier voor de Messias van Israël. Kampen : Kok.

VAN DEN BROM, L.J. e.a. 1998. Verzoening of Koninkrijk. Over de prioriteit in de verkondiging. Leidse lezingen. Nijkerk/Kampen : Callenbach. 
WENTSEL, B. 1991. God en mens verzoend: incarnatie, verzoening, koninkrijk van God. Dogmatiek deel 3b. Kampen : Kok.

\section{Key concepts:}

De-Lutherising Paul

Dunn, James D.C.

justification of sinner: in juxtaposition to kingdom of God new Paul paradigm

\section{Kernbegrippe:}

Dunn, James D.G.

ontlutherianisering van Paulus

paradigma van die "nuwe" Paulus

regverdiging van die sondaar: teenoor koninkryksbegrip 


\title{
Response
}

\section{Kingdom and justification \\ Response to Professor J. van Bruggen's paper "Kingdom of God or the justification of the sinner?"}

\author{
C.J. Wethmar \\ Head: Department of Systematic Theology \\ University of Pretoria \\ RETORIA \\ E-mail: dogmsend@ccnet.up.ac.za
}

\begin{abstract}
Kingdom and justification. Response to Professor J. van Bruggen's paper: "Kingdom of God or the justification of the sinner?"

In this article a response is given to Professor J. van Bruggen's paper "Kingdom of God or justification of the sinner". It is suggested that Van Bruggen's criticism of Dunn's new paradigm in Pauline studies can perhaps be complemented by two further considerations. The first of these is that Dunn's position is not only determined by considerations of a technical, exegetical nature and the corresponding view of the nature and authority of Scripture, but also by the doctrinal tradition to which he belongs. The second is that it could be indicated that the problem which Dunn experiences with the Lutheran interpretation of the justification doctrine does not apply to the Reformed version of this doctrine. The outcome of these considerations is that the necessity for developing Dunn's new paradigm can be questioned.
\end{abstract}

The position that Professor Van Bruggen develops in his paper "The kingdom of God or the justification of the sinner" is that it is impossible to isolate Jesus' message of the kingdom, on the one hand, and the Pauline proclamation of the justification of sinners on the other. As I agree with this position, the task which I have set myself for this response is to emphasise certain issues in Professor Van Bruggen's paper and to ask a few questions with a view to facilitating discussion on the relevance of the topic dealt with in furthering the general theme of the kingdom of God. 


\section{The identity of Christianity}

What should be clear at the outset is that the topic dealt with in the paper under discussion is of a most profound nature. At stake, to my mind, is nothing less than the identity of Christianity. This is also the case in the Netherlands where currently, once again, the question is debated whether the message regarding the atonement in Christ or that regarding the kingdom of God should be given priority in the church's proclamation of the gospel (Van den Brom, 1998). This issue is also relevant in South Africa with its history of controversy between prophetic theology and church theology (Hofmeyr et al., 1987) and with its attempts to deal with the issue of justice and justification in the context of its struggles with truth and reconciliation (Meiring, 1999). In all these debates nothing less than the identity of Christianity is at stake.

\section{Dunn's view: justification primarily a social issue}

In his paper on "Kingdom of God or the justification of the sinner", Professor Van Bruggen took the work of the New Testament scholar, James Dunn, as point of departure. Dunn is of the opinion that the justice of God is primarily a social issue which is unduly restricted when it is dealt with in an individual and personal perspective as happens in the Lutheran doctrine of the justification by faith (Dunn \& Suggate, 1993:28). In fact, Dunn (1983:95-122) develops what he calls a new perspective on Paul according to which it becomes clear to him that Paul's idea of salvation coincides with Jesus' message on the kingdom of God. But this message, he states, in the first place deals with social justice and not with the forgiveness of personal sins. In Dunn's attempt to prove this point Paul becomes delutherised and the gospel becomes dechristologised. The social justice Dunn refers to is a manifestation of God's eschatological rule experienced in the powerful activity of the Holy Spirit (Dunn, 1998:191).

What is Dunn's reason for taking this approach? Professor Van Bruggen argues that, in the last resort, the reason is to be found in Dunn's view and usage of Scripture. According to this view the gospel is not seen as communicating an historical sequence of events but primarily as a collection of original words of Jesus, arranged within a fictional framework of stories. When the Bible as reliable witness regarding the saving events in the life of Jesus is forfeited in this manner, the only access to salvation is the experience of the reign of God in the Spirit.

Regarding the way in which Dunn's views on Scripture influences the manner in which he develops and implements his new perspective on Paul for the sake of emphasising social justice as the essence of 
Christianity, the following question can be asked: should one not also, in this respect, take into account the doctrinal tradition to which Dunn belongs? In his book The living Word in which he develops his ideas on Biblical interpretation and Scriptural authority, Dunn (1987: 6-24) argues that a New Testament interpretation is basically conducted in the form of a dialogue in which both the community of scholarship and the community of faith are involved.

\section{The Anglican tradition}

As an Aglican, Dunn is part of a tradition which takes an exceptional position in Protestantism. It maintains a soteriology which is akin to that of the Eastern Orthodox tradition in which salvation is experienced in a direct relationship between man and God the Father. For this reason the Anglican Church in 1976 rejected the so-called filioque doctrine according to which the Holy Spirit proceeds from the Father alone and not from the Father and the Son (Jonker, 1994:30). As is the case with the Eastern Orthodox Churches the Anglican tradition does not primarily think along hamartocentric lines but rather in terms of a mystical relationship between man and God (Jonker, 1994:21).

I would, therefore, suggest that in addition to the exegetical method which Dunn employs the denominational tradition to which he belongs explains why he adopts the position he defends. The Anglican tradition tends to have scant appreciation for the "metaphors of the law court" - a term used by Dunn to refer to the doctrines of vicarious atonement and justification by faith (Dunn \& Suggate, 1993:36).

It would in passing also be interesting to know how many New Testament scholars share Dunn's new perspective on Paul and therefore his attempt to reduce the justification doctrine to that of the kingdom. My impression is that quite a substantial body of New Testament scholarship still supports the view of a basic continuity between Jesus and Paul and would, therefore, not be willing to support a reduction of the justification doctrine to the proclamation of the Kingdom.

\section{The shift from justification to kingdom}

Another question that could be asked about the basic motive behind the shift of emphasis from justification to kingdom, is whether this may be regarded as part of the present-day process of converting theology into science of religion and of the attempt to make Christianity a mere part of a system of world religions. Where this happens the distinctive character of Christianity has to be suppressed in favour of a general religiosity. A well known example of such an approach was the so-called myth of God 
incarnate debate some two decades ago (Hick, 1977; Harvey, 1981). One has to concede that providing an adequate description of the relationship of world religions towards each other does indeed constitute a major theological challenge in our time. Neglecting fundamental aspects of a specific tradition, and in our case of the Christian faith can, however, not be regarded as a feasible way of meeting this challenge.

\section{The Lutheran tradition tends to restrict the message of salvation}

Having considered the doctrine of Scripture, the basic structure of the Anglican tradition and the emergence of the present-day ecumenical movement as factors possibly determining Dunn's approach to the new Paul paradigm, one further question needs to be asked. Would Dunn's complaint about the Lutheran interpretation of the justification doctrine, namely that it neglects social justice in favour of the justification of the individual, have had the same impact had it been directed not to the Lutheran but to the Reformed doctrine of the justification by faith? I ask this question because Professor Van Bruggen, deliberately refers to the task of the Reformed churches in dealing with this issue towards the end of his paper.

- The Lutheran tradition tends to restrict the message of salvation to justification and the forgiveness of sins (Jonker,1981:183). Within this tradition the following aspects are prominent: Law and gospel are seen as diametrically opposed to each other. The task of the law is mainly to be indicative of sin. The believer is spontaneously led by the Holy Spirit to lead a virtuous life.

- According to the Calvinist approach, however, this work of the Holy Spirit is not done without the Word of God. Within the Calvinist approach the law of God is therefore seen as having a more extensive function than only convincing believers of their sinfulness. It is regarded as indicative of the structure of a virtuous life.

\section{The Reformed tradition}

The Calvinist tradition is therefore also characterised by the so-called tertius usus legis in which this structure is reflected. The Reformed tradition does not only emphasise the justification and the forgiveness of sin but also highlights the sanctification as a gift of God. The Word of God does not only contain the gospel of justification but also the law of sanctification to which the Holy Spirit empowers the believer. In Reformed theology justification by faith does not imply restriction of justice to the personal sphere but also an empowerment to social justice. The 
implication of this position is that it is not necessary to devaluate the justification doctrine in order to appreciate the issue of social justice. In the Reformed tradition they are seen as complementing each other.

\section{Suggestions}

In summing up one could say that my response to Professor Van Bruggen's paper basically consists of two suggestions.

- The first is that, in encountering Dunn's notion of a new Paul paradigm, one should not only take into account considerations of a technical exegetical nature and the view of Scripture on which these views are based. One should also seriously consider the mainly undisclosed doctrinal presuppositions of this new paradigm.

- The second suggestion is that, in responding to Dunn, one could indicate that the problem which he experiences with the Lutheran interpretation of the justification doctrine does not apply to the Reformed version of this doctrine. This view would imply that, in this case, the need which he indicated for developing this new paradigm does not apply.

\section{Bibliography}

DUNN, J.D.G. 1983. The new perspective on Paul. The John Rylands University Library, 65:95-122.

DUNN, J.D.G. 1987. The Living Word. London : SCM.

DUNN, J.D.G. \& SUGGATE, A.M. 1993. The justice of God. A fresh look at the old doctrine of justification by faith. Grand Rapids : Eerdmans.

DUNN, J.D.G. 1998. The theology of Paul the Apostle. Edinburgh : Clark.

HARVEY, A.E., ed. 1981. God incarnate: Story and belief. London : SPCK.

HICK, J., ed. 1977. The myth of God incarnate. London : SCM.

HOFMEYR, J.W., DU TOIT, J.H.H. \& FRONEMANN, C.J.J., reds. 1987. Perspektiewe op Kairos. Kaapstad : Lux Verbi.

JONKER, W.D. 1981. Die Gees van Christus. Pretoria : NGKB.

JONKER, W.D. 1994. Bevrydende waarheid. Die karakter van die gereformeerde belydenis. Wellington : Hugenote-uitgewers.

MEIRING, P. 1999. Kroniek van die waarheidskommissie. Op reis deur die verlede en die hede na die toekoms van Suid-Afrika. Vanderbijlpark : Carpe Diem.

VAN DEN BROM, L.J. et al. 1998. Verzoening of Koninkrijk. Over de prioriteit in de verkondiging. Nijkerk : Callenbach.

\section{Key concepts:}

justification

kingdom

reconciliation

$\sin$

social justice

soteriology

\section{Kernbegrippe:}

koninkryk

regverdiging

sonde

sosiale geregtigheid

soteriologie

versoening 
